\title{
Determination of Genetic Diversity in Apodemus mystacinus (Mammalia: Rodentia) based on
} SSRs

\section{Gül OLGUN KARACAN ${ }^{1 *}$, Dilek BETEȘ ${ }^{2}$}

\begin{abstract}
The aim of this study is to determine the genetic diversity of species in Rocky mouse, Apodemus mystacinus, using SSR (the simple sequence repeat) loci and to reveal the reasons of this variations, if any. In this study, 69 A. mystacinus samples were studied collected from 18 localities in Turkey. 7 SSR loci were used to determine the genetic diversity of $A$. mystacinus. As a result of this study, A. mystacinus includes 2 genetic groups that indicate the presence of two subspecies as $A$. $m$. mystacinus that is distributed in western Anatolia and A. m. euxinus in eastern Anatolia. This result also supports that one of the micro refugium areas is eastern Turkey and the other western and southern Turkey.
\end{abstract}

Keywords: Apodemus mystacinus, microsatellite, Turkey

\section{Apodemus mystacinus'un (Mammalia: Rodentia) Genetik Çeşitliliğinin SSR ile Belirlenmesi}

ÖZET: $\mathrm{Bu}$ çalışmanın amacı, SSR (basit dizi tekrarları) lokuslarını kullanarak kayalık faresinin, Apodemus mystacinus, genetik çeşitliliğini belirlemek ve varsa bu çeşitliliğin nedenleri ortaya koymaktır. Bu çalışmada, Türkiye'deki 18 lokaliteden toplanan 69 A. mystacinus örneği çalışılmıştır. A. mystacinus'un genetik çeşitliliğini belirlemek için 7 SSR lokusu kullanılmıştır. Bu çalışmanın sonucuna göre $A$. mystacinus, iki alttürün varlığını gösteren 2 genetik grup içermektedir; Anadolu'nun batısında A. m. mystacinus ve Anadolu'nun doğusunda A. m. euxinus. Bu sonuç aynı zamanda mikro sığınak alanlarından birinin Türkiye'nin doğusunda, diğerinin ise batısında ve güneyinde olduğunu desteklemektedir.

Anahtar kelimeler: Apodemus mystacinus, mikrosatellit, Türkiye

\footnotetext{
${ }^{1}$ Gül OLGUN KARACAN (Orcid ID: 0000-0002-7160-5766), Aksaray Üniversitesi, Sağlik Hizmetleri Yüksekokulu, 68000, Aksaray, Türkiye

${ }^{2}$ Dilek Beteş (Orcid ID: 0000-0002-3380-5804), Ankara Üniversitesi, Fen Fakültesi, Biyoloji Bölümü, 06000, Ankara, Türkiye

*Sorumlu Yazar/Corresponding Author: Gül Olgun Karacan, e-mail: glolgn@gmail.com

Bu çalışma Ankara üniversitesi Bilimsel Araştırma Koordinatörlüğü Birimi tarafından (BAP: 14B0430001) desteklenmiş olup, 5-8 Temmuz 2017 tarihleri arasında Belarus'ta düzenlenmiş olan SEAB2017 isimli kongrede sözlü sunum olarak sunulmuştur. Ayrıca 21-23 Ekim 2016 tarihinde Konya'da düzenlenmiş olan International conference on Biological Sciences isimli kongrede poster olarak tebliğ edilmiştir.
}

ETIK KURUL ONAYI / ETHICS COMMITTEE APPROVAL: Bu makale yer alan hayvan deneyi için "Ankara Üniversitesi Rektörlüğü Hayvan Deneyleri Yerel Etik Kurulu"nun Tarih: 30.10.2013 Toplantı No 2013-19, Dosya No: 2013-117 ve Karar No:2013-19-142 sayılı kararı ile Etik Kurul Onayı almıştır. 


\section{INTRODUCTION}

The rocky mouse, Apodemus mystacinus, is one of the rodent species widely distributed in Turkey. This species lives in rocky areas covered with forests reaching up to a height of $2700 \mathrm{~m}$ (Çolak et al., 2004). A. mystacinus can be easily separated from the other European Apodemus by different characters such as its larger body size and dark grey fur coloration (Michaux et al., 2005).

Although four subspecies were described as A. m. mystacinus Danford and Alston (1877) from Sebil, Turkey; A. m. smyrnensis Thomas (1903) from western Turkey; A. m. rhodius Festa (1914) from Rhodes and Crete; and A. m. euxinus Allen (1915) from Altındere, Turkey, the distribution areas and the validities of these subspecies are controversial.

According to some authors, A. $m$. smyrnensis is one of the subspecies that lives in western Anatolia (Çolak et al., 2007; Olgun et al., 2009; Olgun Karacan et al., 2015). Neuhauser (1936) reported that A. m. smyrnensis was distributed in western Turkey and in the Taurus mountains using morphological data. Çolak et al. (2007) suggested that İzmir, Aydın and Bursa specimens of A. mystacinus were different from the other specimens collected from Anatolia based on esterase variations and researchers claimed that these western specimens might be A. m. smyrnensis. The differentiation of the specimens that was distributed in western Turkey was supported using RAPD (Olgun et al., 2009) and mtDNARFLP (Olgun Karacan et al., 2015) variations. On the other hand, some researchers have claimed that A. m. symrnensis is synonymous with A. m. mystacinus based on morphological, biometrical, karyological, studies and bacular, phallic differentiations (Ellerman, 1948; Ellerman and Morrison-Scott, 1951; Çolak et al., 2004).

The other controversial subspecies is $A . m$. euxinus (Allen, 1915), and while some studies indicated that northern or northeastern Anatolia is the distribution area of this subspecies using morphological data (Neuhaser, 1936) and esterase variations (Çolak et al, 2007), others claimed the homogeneity of northeastern and eastern Anatolian populations depend on biometric measurements (Çolak et al., 2004) and genetic data Olgun et al., 2009; Olgun Karacan et al., 2015).

Michaux et al. (2005) has revealed that there is a different lineage that is distributed in southwestern Turkey and Crete using molecular data, and researchers has called these specimens as A. m. rhodius. Similarly, Olgun et al. (2009) has showed two different lineages in western Turkey based on RAPD markers, and one of them has included Muğla specimens in the southwestern part. However, the validity of $A . m$. rhodius hasn't been supported by morphological (Ellerman, 1948; Vohralik et al., 2002; Çolak et al., 2004) and mtDNA-RFLP studies (Olgun Karacan et al., 2015).

Major fluctuations in the climate during late Pliocene and Pleistocene have affected populations (Hewitt, 1996). Also, the formation of biodiversity is directly related to climate change (Ficetola et al., 2017). Jandzik et al. (2018) have claimed that the climatic changes that occurred during the Pleistocene played important roles in shaping the diversity of Western Palaearctic biota and its present distribution. The refuges of the glacial periods during Pleistocene are the most important factors that clarify the biogeographic patterns in present day in Europe (Schmitt, 2007; Svenning and Skov, 2007). Turkey is one of the refugia including mountain ranges such as Anatolian Diagonal, and Taurus and Black Sea mountains and many seaways (Black, Aegean, and Mediterranean seas) that inhibited gene flow between populations (Bilgin, 2011). Especially, Anatolian Diagonal has acted as an important biogeographical barrier by dividing the lines or species into eastern and western parts (Hewitt, 
1999, 2000; Veith et al., 2003; Çıplak, 2003, 2004; Mutun, 2010; Bilgin, 2011; Plötner et al., 2010; Kapli et al., 2013; Özdemir et al., 2014; Allegrucci et al., 2017; Riemsdijk et al., 2017; Yiğit et al., 2017).

DNA phylogenies may particularly be useful to present lineages, subspecies, and species (Hewitt, 1996). Animal mtDNA and nuclear genes are useful tools to understand the evolutionary history of these lineages, especially in Pleistocene (Avise et al., 1998; Michaux et al., 2002, 2003, 2004; Jaarola et al., 2004; Suzuki et al., 2003, 2004, 2008; Hewitt 2004; Deffointaine et al., 2005, 2009; Macholan et al., 2007; Hürner et al., 2010; Avise and Tatarenkov, 2012; Çolak et al., 2016). Microsatellite has high polymorphism, high and rapid mutation rate $\left(10^{-}\right.$ $\left.{ }^{3}-10^{-4}\right)$ and small repetitive regions in genome and they are preferred to reveal differentiations between closer populations (Chiappero et al., 2011; Burgos-Pas et al., 2011; Gortat et al., 2013). Thus, in the present study we used microsatellites: (1) to determine the relationships among A. msytacinus specimens in Turkey, (2) to define the validity of the subspecies, (3) to explain the reasons of the speciation in $A$. mystacinus.

\section{MATERIAL AND METHODS}

A total of 69 specimens were collected from 18 different Turkish localities (Figure 1). Total DNA was extracted from kidneys by CTAB method (Doyle and Doyle 1991). The 7 microsatellites primers (GTTD8S, GTTF9A, GACAA12A, GACAD1A, GATAE10A, GTTD9A, MSAF-8) were chosen to amplify (Gockel et al., 1997; Makova et al., 1998). Primers were labelled by using 2 different fluorescent dyes, HEX and 6-FAM. Polymerase chain reaction (PCR) were carried out in final volumes of $25 \mathrm{ul}$ with $80 \mathrm{ng}$ of the DNA samples (Çolak et al., 2016).

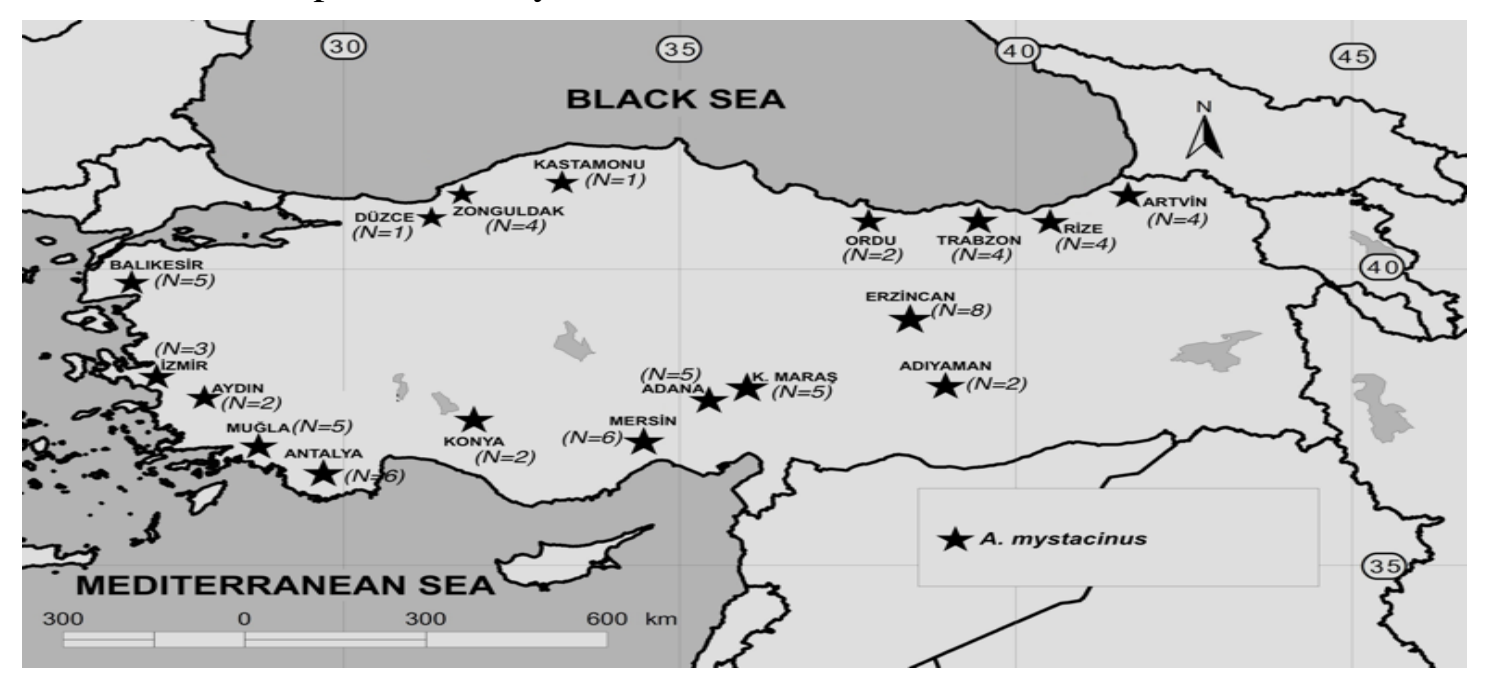

Figure 1. Collected areas and the number of specimens (N)

Amplification of microsatellite loci was performed as: an initial denaturation step at 94 ${ }^{\circ} \mathrm{C}$ for $3 \mathrm{~min}$, followed by 35 cycles of denaturation at $94{ }^{\circ} \mathrm{C}$ for $1 \mathrm{~min}$, annealing at 55 $60{ }^{\circ} \mathrm{C}$ for $30-45 \mathrm{~s}$, and extension at $72{ }^{\circ} \mathrm{C}$ for 45 $\mathrm{s}-1 \mathrm{~min}$. After PCR, products were visualized on $2 \%$ agarose gel and analysed on an ABI PRISM 3100 Genetic Analyzer (Applied Biosystems).
Electropherograms were evaluated using the Applied Biosystems Peak Scanner program (http://www. appliedbiosystems.com).

Firstly, microsatellite profiles were tested for the presence of null alleles to eliminate the scoring errors with FreeNA software (Chapuis and Estoup, 2007). Genetic polymorphism within specimens was determined as the mean 
number of alleles per locus (A), polymorphic loci $(\mathrm{P} \%)$, and observed (Ho) and expected heterozygosity (He) using GENETIX software version 4.05.2 (Belkhir et al., 2004). This program was also used to calculate allelic richness (AR). In addition, genetic structure was examined using the factorial correspondence analyses (FCA) of individual differentiation in GENETIX software. Private allelles and frequencies are calculated with GenAlex 6.5 (Peakal and Smouse, 2012). The degrees of genetic differentiation (FST) values and genetic distance $\left(D_{C}\right)$ (Cavalli-Sforza and Edwards, 1967) among groups were analysed using FreeNA software. Neighbour-Joining (NJ) tree was constructed by MEGA 6.06 software using genetic distance data $\left(D_{C}\right)$ (Tamura et al., 2013). The Analysis of Molecular Variance (AMOVA) test was executed for 2 different groupings on phylogenetic tree using ARLEQUIN v. 3.5 (Excoffier and Lischer, 2010). Bayesian structure analysis was run using STRUCTURE 2.1 (Pritchard et al.,2000; Falush et al., 2007). The result of STRUCTURE software was K that was indicated the number of populations calculated by allele frequencies.

\section{RESULTS AND DISCUSSION}

Initially, to determine the reliability of the microsatellite data set, the null (silent) allele frequencies for each population and locus were calculated. 0.2 and above are considered as invalid since the frequency values (r) will create problems for statistical analysis. Therefore, we didn't use the $4.7 \%$ of the performed tests (six out of 126) for the analysis.

The analysis of 7 microsatellite loci in 69 A. mystacinus, from 18 locations showed low levels of variability. The mean number of alleles (A) ranged from 1.00 (Kastamonu) to 2.8571 (Erzincan) and allelic richness (AR) from 7.00 (Kastamonu) to 9.78 (Erzincan) (Table 1).

Ho and He values were almost the same at different localities. The observed and expected heterozygosity values varied from 0.00 (Kastamonu) to 0.2857 (Ordu) and 0.00 (Kastamonu) to 0.3713 (Erzincan) (Table 1). The mean number of polymorphic loci $(\mathrm{P} \%)$, and observed (Ho) and expected heterozygosity (He) were found to be significantly different between two groups. Besides, heterozygosity was higher than expected, that we might suspect an isolatebreaking effect (the mixing of two previously isolated populations) between the eastern and western groups of A. mystacinus.

Genetic relationships among populations were calculated by pairwise FST. The FST values ranged from - 0.1185 (between Düzce and İzmir) to 0.7261 (between Konya and Kastamonu). FST values were indicated the possibility of 2 subpopulations among all samples. The number of clusters $(\mathrm{K})$ varied from $\mathrm{K}=1$ to 7 , the highest number of clusters supporting these two subpopulations was 2 (Figure 2).

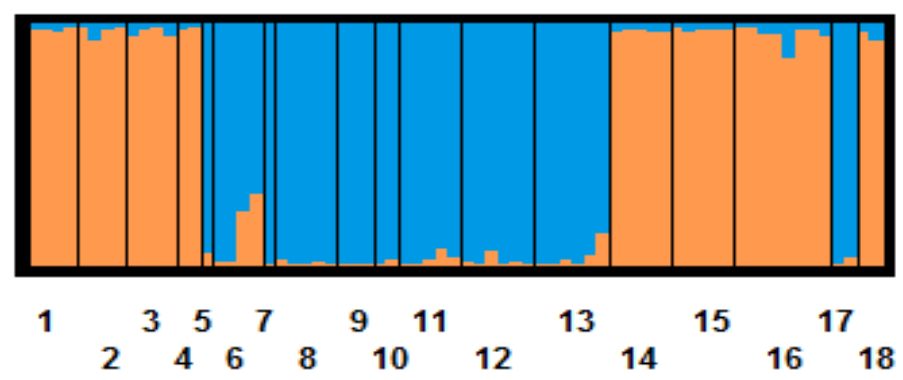

Figure 2. Bayesian structure analysis of individual genotypes in A. mystacinus samples**1: Artvin. 2: Rize. 3: Trabzon. 4: Ordu. 5: Kastamonu. 6: Zonguldak. 7: Düzce. 8: Balıkesir. 9: İzmir. 10: Aydın. 11: Muğla. 12: Antalya. 13: Mersin. 14: Adana. 15: Maraş. 16: Erzincan. 17: Konya. 18: Adıyaman 
Table 1. The overall level of variability in the 18 localities.

\begin{tabular}{|c|c|c|c|c|c|c|c|c|}
\hline Group & Location & He & $\mathbf{H}$ & Ho & $\mathbf{P}$ & $\mathbf{A}$ & np & $\mathbf{A R}$ \\
\hline \multirow{10}{*}{1 East } & Ardanuç-Artvin & 0.2659 & 0.3088 & 0.381 & 0.5714 & 1.8571 & 0 & 8.465 \\
\hline & Çamlıhemşin-Rize & 0.2679 & 0.3061 & 0.4286 & 0.5714 & 1.7143 & 0 & 9.000 \\
\hline & Altındere-Trabzon & 0.2589 & 0.2959 & 0.3214 & 0.5714 & 1.7143 & 0 & 8.467 \\
\hline & Gürgentepe-Ordu & 0.2857 & 0.381 & 0.5 & 0.5714 & 1.7143 & 0 & 9.032 \\
\hline & Feke-Adana & 0.3571 & 0.3968 & 0.4286 & 0.5714 & 2.5714 & 0 & 9.500 \\
\hline & Püren Geçidi-Kahramanmaraş & 0.3057 & 0.3397 & 0.4 & 0.5714 & 2.1429 & 0.1 & 9.756 \\
\hline & Kemaliye-Erzincan & 0.3713 & 0.3971 & 0.3699 & 0.8571 & 2.8571 & 0 & 9.780 \\
\hline & Nemrut-Adiyaman & 0.2857 & 0.381 & 0.4286 & 0.5714 & 1.7143 & 0 & 9.697 \\
\hline & Kastamonu & 0 & 0 & 0 & 0 & 1 & 0 & 7 \\
\hline & Mean & 0.266 & 0.311 & 0.362 & 0.540 & 1.80 & 0.011 & 9.182 \\
\hline \multirow{10}{*}{2 West } & Zonguldak & 0.183 & 0.2092 & 0.1786 & 0.4286 & 1.7143 & 0 & 9.000 \\
\hline & Akçakoca-Düzce & 0.1429 & 0.2857 & 0.2857 & 0.2857 & 1.2857 & 0 & 8.467 \\
\hline & Kaz Dağ1-Balıkesir & 0.1886 & 0.2095 & 0.2571 & 0.2857 & 1.8571 & 0 & 9.032 \\
\hline & Kemalpaşa-İzmir & 0.2361 & 0.2905 & 0.2143 & 0.7143 & 1.7143 & 0 & 9.500 \\
\hline & Buharkent-Aydın & 0.2679 & 0.3571 & 0.2857 & 0.5714 & 1.7143 & 0 & 9.756 \\
\hline & Köyceğiz-Muğla & 0.3543 & 0.3937 & 0.3714 & 0.7143 & 2.7143 & 0.1 & 8.000 \\
\hline & Beyşehir-Konya & 0.1071 & 0.1429 & 0.1429 & 0.2857 & 1.2857 & 0 & 9.697 \\
\hline & Çığılıkara Milli Parkı-Antalya & 0.3532 & 0.3853 & 0.2619 & 0.7143 & 2.4286 & 0 & 9.531 \\
\hline & Sebil-Mersin & 0.3313 & 0.3615 & 0.2143 & 0.7143 & 2.5714 & 0.083 & 9.049 \\
\hline & Mean & 0.270 & 0.327 & 0.285 & 0.583 & 2.232 & 0.021 & 9.115 \\
\hline
\end{tabular}

The phylogenetic analyses and the FCA indicate the existence of two lineages of rocky mouse in Turkey (Figure 3 and 4). The first lineage (the western Turkey) includes the specimens from Kastamonu, Zonguldak, Düzce, Balıkesir, İzmir, Aydın, Muğla, Konya, Antalya and Mersin. The second one (the eastern Turkey) comprises the specimens of Artvin, Rize,
Trabzon, Ordu, Adana, Kahramanmaraş, Erzincan and Adryaman. These lineages indicate two subspecies of $A$. mystacinus in the literature as: A. m. mystacinus (western Turkey) and A. $m$. euxinus (eastern Turkey). The SSR loci weren't useful to support the validity of $A$. m. smyrnensis that was claimed to live in western Turkey.

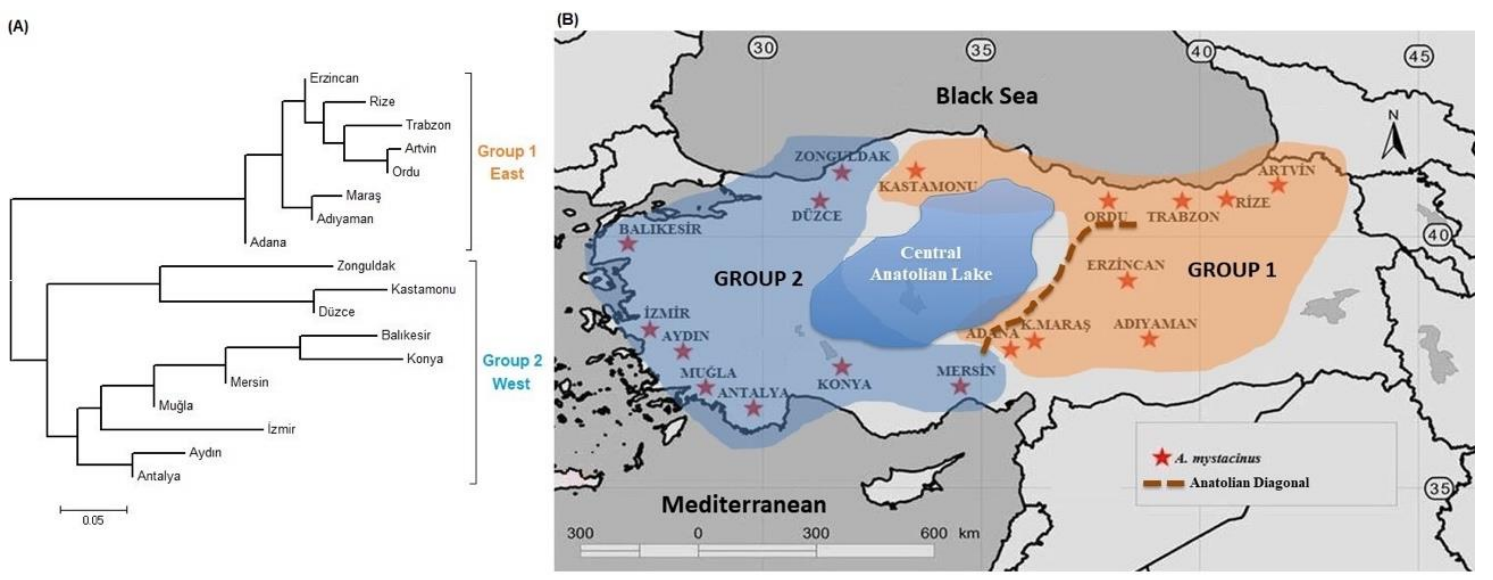

Figure 3. The unrooted Neighbour-Joining tree (A), and the distribution patterns and the isolation barriers of the groups in Anatolia (B) 


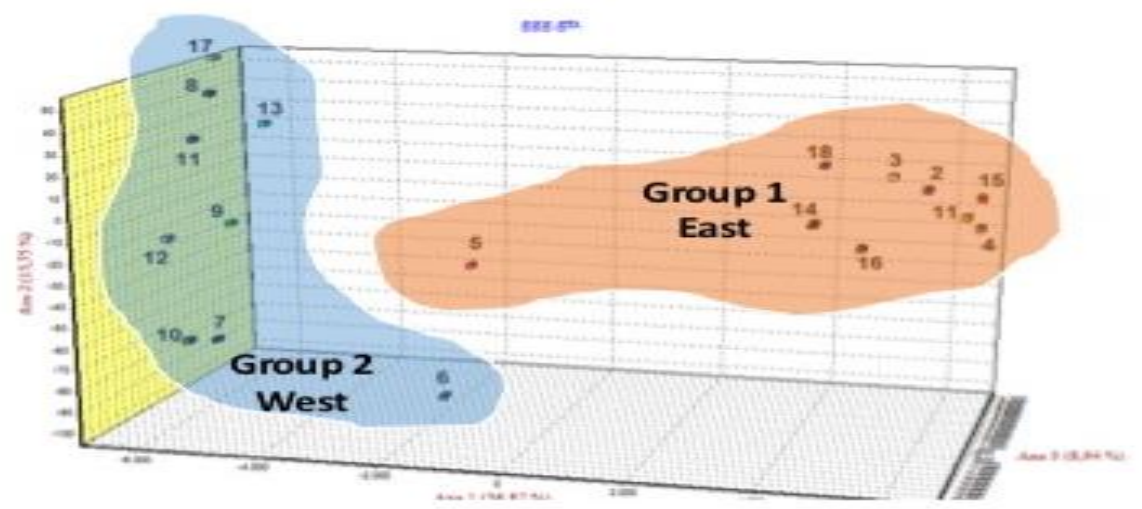

Figure 4. The Factorial Correspondence Analysis of A. mystacinus indicated two Turkish groups

Two of 4 new private alleles were determined in the Group 2 (western turkey) (Table 2). The less frequency of private alleles in A. mystacinus groups $(5 \%<)$ indicate the high level of gene flow. Besides, AMOVA displayed these two major groups of A. mystacinus namely the most percentage of variations were shared among groups $(29.63 \%)$ while it was low within groups $(10.16 \%)$ (Table 3). This result also indicate that the ongoing gene flow between two $A$. mystacinus subpopulations.

Table 2. Distribution and the frequencies of the private alleles

\begin{tabular}{llll}
\hline Population & Loci & Allele & Frequency \\
\hline Muğla & GTTD9A & 201 & 0.100 \\
Mersin & GTTD9A & 205 & 0.083 \\
Kahramanmaraş & GTTF9A & 102 & 0.100 \\
Kahramanmaraş & GACAD1A & 150 & 0.100 \\
\hline
\end{tabular}

Table 3. Analysis of molecular variance between A. mystacinus subpopulations

\begin{tabular}{lcccc}
\hline Source of variation & DF* & Sum of squares & Variance components & Percentage of variation (\%) \\
\hline Among groups & 1 & 41.178 & $0.55442 \mathrm{Va}$ & 29.63 \\
Among populations within groups & 16 & 40.649 & $0.19011 \mathrm{Vb}$ & 10.16 \\
Within groups & 120 & 135.158 & $1.12632 \mathrm{Vc}$ & 60.2 \\
Total & 137 & 216.986 & 1.87085 \\
\hline Fixation index & & & \\
\hline $\mathrm{F}_{\mathrm{ST}} 0.39796$ & $\mathrm{Vc}(\mathrm{P}=0.00000+-0.00000)$ & & \\
$\mathrm{F}_{\mathrm{SC}} 0.14441$ & $\mathrm{Vb}(\mathrm{P}=0.00000+-0.00000)$ & & \\
$\mathrm{F}_{\mathrm{CT}} 0.29635$ & $\mathrm{Va}(\mathrm{P}=0.00000+-0.00000)$ & & \\
\hline
\end{tabular}

In this study, we exhibit that the rocky mouse has two lineages and also support the existence of regional variations or refuge areas as western and eastern in Anatolia. Two possible reason could cause this genetic differentiation: the central Anatolian Lake and the Anatolian Diagonal. One of the reasons of these regional variations could be the existence of the central
Anatolian lake during the Pliocene (Figure 3). This lake system partitioned Anatolia and this might have interrupted the gene flow among populations around. Additionally, the effect of the Kizilirmak Delta, that was connected with central Anatolian lake system in Pliocene (5.3$2.6 \mathrm{Mya})$, on gene flow among A. mystacinus specimens was presented using $C y t b$ gene and 
RFLP markers (Olgun Karacan $\mathrm{PhD}$ thesis, 2013; Olgun Karacan et al., 2015).

The other potential reason is the Anatolian Diagonal extends from northeastern Turkey (Bayburt, Gumushane close) to southwestward and is divided into two branches toward the Mediterranean: Central Taurus Mountains and the Nur Mountains (Gür, 2017). This mountain range is a physical and an ecological barrier between populations in East-West side of it (Gündüz et al., 2007; Mutun, 2010, 2016; Mutun and Atay, 2015; Gür, 2016). Furthermore, Gündüz et al., (2007), found that the two phlogroups of the Anatolian squirrel were located on the Anatolian Diagonal, and that these two phylogroups were likely to have occupied the LGM refuges around the Anatolian Diagonal. Similarly, Mutun (2016) revealed that there were glacial refuges on both sides of the Anatolian Diagonal. In this study, it has been shown that the Anatolian Diagonal serves as a barrier in separating the two lineages of $A$. mystacinus (Figure 3). Regions where genetic diversity is high could be considered as a refuge area that the populations could survive during glacial periods in Pleistocene (Hewitt, 1996; Michaux et al., 2005). Climate and vegetation changes during Plio-Pleistocene caused cooling down and drought in the Mediterranean. Different habitats in low places functioned as glacial refugees and populations in these refugees were differentiated into new lineages during interglacial period. (Hewitt, 1996). Kosswigg (1955), suggested two Anatolian glacial refugia, one in western Anatolia and one in eastern Anatolia, based on non-genetic data. These regional variations was also supported by the genetic and morphometric studies on some animals distributed in Turkey like small mammals and amphibians (Çıplak, 2004; Fritz et al., 2009; Gvozdik et al., 2010; Çolak et al., 2016; İbiş et al., 2017; Gür et al., 2017; Şeker et al., 2018). Gvozdik et al. (2010) revealed that the Anatolian and Caucasus-Caspian were an important Pleistocene refuge for $H$. orientalis. Also, phylogeographic and demographic data suggest Anatolia as an ancient glacial refuge for turtles (Fritz et al. 2009). Furthermore, the existence of different micro refugium areas especially in the Black Sea region were also demonstrated (Fritz et al., 2009). Çıplak (2004), indicated that southern Anatolia was a refuge for Anterastes populations. Çolak et al. (2016) presented the regional refuges in northern Anatolia. Gür et al. (2017) showed that the Taurus Mountains served as a refuge where the grand squirrels of the inhabitants moved to the higher latitudes in warm periods since the Last Glacial Maxima. Moreover, Şeker et al. (2018) has considered Anatolia as a potential glacial refuge in Pleistocene because of the high genetic variability in Turkish water vole populations. In this context, Adana and Erzincan specimens from the eastern side of diagonal and Antalya and Muğla specimens from the western side of the diagonal show higher genetic variability than from the other specimens indicate that these regions might be the potential refuge areas (Table 1).

\section{CONCLUSION}

Thus, we achieved two important results in this study: One is the subspeciation of A. mystacinus: the SSR loci show the validity of only two subspecies distribute in Turkey: $A . m$. mystacinus and A. m. euxinus. The other important result is the supporting the presence of glacial refugium areas in Turkey using SSR loci. More information about the central Anatolian specimens will also help us to clarify rocky mouse distribution and subspeciation process or the hybrid zones where the refugium specimens make contact refugium in Anatolia in future.

\section{ACKNOWLEDGEMENTS}

This study was supported by Ankara University, Scientific Research Projects Coordination Unit (BAPRO: 14B0430001). We 
would like to thank to Prof. Dr. Reyhan ÇOLAK and Prof. Dr. Ercüment ÇOLAK for sharing their valuable contributions, equipments and collecting specimens in this study.

\section{REFERENCES}

Allegrucci G, Ketmaier V, Di Russo C, Rampini M, Sbordoni V, Cobolli M, 2017. Molecular phylogeography of Troglophilus cave crickets (Orthoptera, Rhaphidophoridae): A combination of vicariance and dispersal drove diversification in the East Mediterranean region. Journal of Zoological Systematic and Evolutionary Research, 55: 310-325.

Avise JC, Tatarenkov A, 2012. Allard's argument versus Baker's contention for the adaptive significance of selfing in a hermaphroditic fish. Proceedings of the National Academics and Science, 109: 18862-18867.

Avise JC, Walker D, Johns GC, 1998. Speciation durations and Pleistocene effects on vertebrate phylogeography. Proceedings Biological Science, 265: 1707-1712.

Belkhir K, Borsa P, Chikhi L, Raufaste N, et Bonhomme F, 2004. GENETIX 4.05, logiciel sous Windows pour la genetique des populations. Universite de Montpellier II, Montpellier, France.

Bilgin R, 2011. Back to the Suture: The distribution of genetic diversity in and around Anatolia. International Journal of Molecular Sciences, 12: 4080-4103.

Burgos-Paz W, Ceron-Munoz M, SolartePortilla C, 2011. Genetic diversity and population structure of the Guinea pig (Cavia porcellus, Rodentia, Caviidae) in Colombia. Genetics and Molecular Biology, 34: 711-718.

Cavalli-Sforza LL, Edwards AWF, 1967. Phylogenetic analysis: models and estimation procedures. Evolution, 21: 550-570.

Chapuis MP, Estoup A, 2007. Microsatellite Null Alleles and Estimation of Population Differentiation. Molecular Biology and Evolution, 24(3): 621-631.

Chiappero MB, Panzetta-Dutari GM, Gómez D, Castillo E, Polop JJ, Gardenal CN, 2011. Contrasting genetic structure of urban and rural populations of the wild rodent Calomys musculinus

(Cricetidae, Sigmodontinae). Mammalian Biology, 76: 4150.
Çıplak B, 2003. Distribution of Tettigoniinae (Orthoptera, Tettigoniidae) bushcrickets in Turkey: the importance of the Anatolian Taurus Mountains in biodiversity and implications for conservation. Biodiversity and Conserversation, 12: 47-64.

Çıplak B, 2004. Biogeography of anatolia: the marker group orthoptera. Memmorie della Societa Entomologica Italina, 82: 357-372.

Çolak E, Yiğit N, Çolak R, Sözen M, Özkurt Ş, Kankılıç T, 2004. Taxonomic Status and Distribution of Apodemus mystacinus (Danford and Alston, 1877) (Mammalia: Rodentia) in Turkey. Turkish Journal of Zoology, 28: 285-294.

Çolak R, Kandemir İ, Çolak E, Yiğit N, 2007. Esterase Variation in Rocky Mouse, Apodemus mystacinus (DanforD and alston, 1877) (Mammalia: Rodentia) in Turkey. Acta Zoologica Bulgarica, 59 (1): 47-52.

Çolak R, Olgun Karacan G, Kandemir İ, Çolak E, Kankılıç T, Yiğit N, Michaux J, 2016. Genetic variations of Turkish bank vole, Myodes glareolus (Mammalia: Rodentia) inferred from mtDNA. Mitochondrial DNA, 27(6): 43724379.

Deffontaine V, Ledevin R, Fontaine MC, Quéré J-, Renaud S, Libois R, Michaux JR, 2009. Relict bank vole lineage highlights the biogeographic history of the Pyrenean region in Europe. Molecular Ecology, 18: 2489-2502.

Deffontaine V, Libois R, Kotlik P, 2005. Beyond the Mediterranean peninsulas: Evidence of Central European glacial refugia for a temperate forest mammal species, the bank vole (Clethrionomys glareolus). Molecular Ecology, 14: 1727-1739.

Doyle JJ, Doyle JL, 1991. Isolation of plant DNA from fresh tissiue. Focus, 12 (1): 13-15.

Ellerman JR, 1948. Key to The Rodents of Southwest Asia in the British Museum Collection. Proceedings of the Zoological Society of London, 118: 765-816.

Ellerman, JR, Morrison-Scott TCS, 1951. Checklist of Plaearctic and Indian Mammals. London: British Museum of National History.

Excoffier L, Lischer H EL, 2010. Arlequin suite ver 3.5: A new series of programs to perform population genetics analyses under Linux and Windows. Molecular Ecology Resources, 10: 564-567. 
Falush D, Stephens M, Pritchard JK, 2007. Inference of population structure using multilocus genotype data: dominant markers and null alleles. Molecular Ecology Notes, 7(4): 574578.

Ficetola GF, Mazel F, Thuiller W, 2017. Global determinants of zoogeographical boundaries. Nature Ecology and Evolution, 1: 0089.

Fritz U, Ayaz D, Hundsdörfer AK, Kotenko T, Guicking D, Wink M, Tok V, Çiçek K, Buschbom J, 2009. Mitochondrial diversity of European pond turtles (Emys orbicularis) in Anatolia and Ponto-Capian Region: Multiple old refuges, hotspot of extant diversification and critically endangered endemics. Organisms Diverity and Evolution, 9: 100-114.

Gockel J, Harr B, Schlötterer C, Arnold W, Gerlach G, Tautz D, 1997. Isolation and characterization of microsatellite loci from Apodemus flavicollis (rodentia, muridae) and Clethrionomys glareolus (Rodentia, Cricetidae). Molecular Ecology, 6: 597-599.

Gortat T, Rutkowski R, Gryczynska-Siemiatkowska A, Kozakiewicz A, Kozakiewicz M, 2013. Genetic structure in urban and rural populations of Apodemus agrarius in Poland. Mammalian Biology, 78: 171-177.

Gündüz I, Jaarola M, Tez C, Yeniyurt C, Polly PD, Searle JB, 2007. Multigenic and morphometric differentiation of ground squirrels (Spermophilus, Sciuridae, Rodentia) in Turkey, with a description of a new species. Molecular Phylogenetics and Evolution, 43: 36.

Gür H, 2016. The Anatolian diagonal revisited: Testing the ecological basis of a biogeographic boundary. Zoology in the Middle East, 62:189-199.

Gür H, 2017. Anadolu diyagonali: Bir biyocoğrafi sınırın anatomisi. Kebikeç, İnsan Bilimleri İçin Kaynak Araştırmaları Dergisi, 43: 177-187.

Gür H, Perktaş U, Gür MK, 2017. Do climate-driven altitudinal range shifts explain the intraspecific diversification of a narrow ranging montane mammal, Taurus ground squirrels? Mammal Research, 63:1-15.
Gvozdik V, Moravec, Klütsch C, Kotlik P, 2010. Phylogeography of the Middle Eastern tree frogs (Hyla, Hylidae, Amphibia) as inferred from nuclear and mitochondrial DNA variation, with a description of a new species. Molecular Phylogenetics and Evoution, 55: 1146-1166.

Hewitt G, 1996. Some genetic consequence of ice ages, and their role in diverging and speciation. Biological Journal of the Linnean Society, 58: 247-276.

Hewitt GM, 1999. Post-glacial recolonisation of European biota. Biological Journal of the Linnean Society, 58: 87-112.

Hewitt GM, 2000. The genetic legacy of the Quaternary ice ages. Nature, 405: 907-913.

Hewitt GM, 2004. The structure of biodiversity insights from molecular phylogeography. Frontiers in Zoology, 1: 4.

Hurner H, Krystufek B, Sara M, Ribas A, Ruc T., Sommer R, 2010. Mitochondrial phylogeography of the edible dormouse (Glis glis) in the western Palearctic region. Journal of Mammalogy, 91(1): 233-242.

İbiş O, Koepfli K-P, Özcan S, Tez C, 2018. Genetic analysis of Turkish martens: Do two species of the genus Martes occur in Anatolia? Zoologica Scripta, 47: 390-403.

Jaarola M, Martınkova N, Gündüz İ, Brunhoff C, Zima J, Nadachowski A. et al., 2004. Molecular phylogeny of the speciose vole genus Microtus (Arvicolinae, Rodentia) inferred from mitochondrial DNA sequences. Molecular Phylogenetics and Evolution, 33: 647-663.

Jandzik D, Jablonski D, Zinenko O, Kukushkin OV, Moravec J, Gvoždík V, 2018. Pleistocene extinctions and recent expansions in an anguid lizard of the genus Pseudopus. Zoologica Scripta, 47:21-32.

Kapli K, Botoni D, Ilgaz Ç, Kumlutaş Y, Avc A, Rastegar-Pouyani N, Fathinia B, Lymberakis P, Ahmadzadeh F, Poulakakis N, 2013. Molecular phylogeny and historical biogeography of the Anatolian lizard Apathya (Squamata, Lacertidae). Molecular Phylogenetics and Evolution, 66: 992-1001. 
Kosswigg C, 1955. Zoogeography of the Near East. Sysematical Zoology, 4: 49-73.

Macholan M, Munclinger P, Sugerkova M, Dufkova P, Bimova B, Bozikova E, Zima J, Pialek J, 2007. Genetic Analysis Of Autosomal And XLinked Markers Across A Mouse Hybrid Zone. Evolution, 61(4): 746-771.

Makova KD, Patton JC, Chesser RK, Krysanov EYu, Baker RJ, 1998. Microsatellite markers in wood mouse and striped field mouse (genus Apodemus). Molecular Ecology, 7: 247-248.

Michaux J, Bellinvia E, Lymberakis $P$, 2005.Taxonomy, evolutionary history and biogeography of the broad-toothed field mouse (Apodemus mystacinus) in the eastern Mediterranean area based on mitochondrial and nuclear genes. Biological Journal of the Linnean Society, 85: 53-63.

Michaux JR, Chevret P, Filippucci MG, Macholán M, 2002. Phylogeny of the genus Apodemus with a special emphasis on the subgenus Sylvaemus using the nuclear IRBP gene and two mitochondrial markers: cytochrome $\mathrm{b}$ and 12S rRNA. Molecular Phylogenetics and Evolution, 23: 123-136.

Michaux JR, Filippucci M-G, Libois R, 2004. Phylogeographic history of the yellow-necked fieldmouse (Apodemus flavicollis) in Europe and in the Near and Middle East. Molecular Phylogenetics and Evolution, 32: 188-198.

Michaux JR, Magnanou E, Paradis E, Nieberding C, Libois RM, 2003. Mitochondrial phylogeography of the woodmouse (Apodemus sylvaticus) in the Western Palearctic region. Molecular Ecology, 12: 685-697.

Mutun S, 2010. Intraspecific Genetic Variation and Phylogeography of the Oak Gallwasp Andricus caputmedusae (Hymenoptera: Cynipidae): Effects of the Anatolian Diagonal. Acta Zoologica Academiae Scientiarum Hungaricae, 56: 153-172.

Mutun S, 2016. Molecular diversity and phylogeography of Andricus curtisii (Hymenoptera, Cynipidae) in Turkey. Biochemical Systematics and Ecology, 67: 7485.
Mutun S, Gamze A, 2015. Phylogeography of Trigonaspis synaspis (Hymenoptera: Cynipidae) from Anatolia based on mitochondrial and nuclear DNA sequences. European Journal of Entomology, 112: 259269.

Neuhauser G, 1936. Die Muriden von Kleinasien. Zeitschrift für Saugetierkd, 11: 161-236.

Olgun G, Çolak R, Kandemir İ, Çolak E, Yiğit N, 2009. Genetic variation in Rocky Mouse, Apodemus mystacinus (Danford \& Alston 1877) (Mammalia: Rodentia) in Turkey. Acta Zoologica Bulgarica, 61(2): 123-129.

Olgun Karacan G, 2013. Türkiye'deki Apodemus mystacinus (Mammalia: Rodentia)'un Mtdna (sitokrom b ve kontrol bölgesi) RFLP ve DNA dizi analizi. Ankara University Institute of Science and Technology, $\mathrm{PhD}$ Thesis (Unpublished).

Olgun Karacan G, Çolak R, Çolak E, 2015. Determination of genetic variations between Apodemus mystacinus populations distributed in Turkey inferred from mtDNA PCR-RFLP. Turkish Journal of Zoology, 39: 630-642.

Özdemir N, Gül S, Poyarkov NA, Kutrup B, Tosunoğlu M, Doglio S, 2014. Molecular systematics and phylogeography of Bufotes variabilis(syn. Pseudepidalea variabilis) (Pallas, 1769) in Turkey. Turkish Journal of Zoology, 38: 412-420.

Peakall R, Smouse PE, 2012. GenAlEx 6.5: genetic analysis in Excel. Population genetic software for teaching and research - an update. Bioinformatics, 28: 2537-2539.

Plötner J, Uzzell T, Beerli P, Akın Ç, Bilgin CC, Haefeli C, Ohst T, Köhler F, Schreiber R, Guex G-D, Litvinchuk AN, Westaway R, Reyer H-U, Hotz H, 2010. Genetic divergence and evolution of reproductive isolation in eastern Mediterranean water frogs, pp. 372403. In M. Glaubrecht \& H. Schneider (eds.), Evolution in action. Case studies in adaptive radiation and the origin of biodiversity. Special volume from the SPP 1127 "Radiations Genesis of Biological Diversity" of the DFG. Heidelberg, Berlin: Springer. 
Pritchard JK, Stephens M, Donnelly P, 2000. Inference of Population Structure Using Multilocus Genotype Data. Genetics, 155(2): 945-959.

Riemsdijk I, Arntzen JW, Bogaerts S, Franzen M, Litvinchuk SN, Kurtuluş O, Wielstra B, 2017. The Near East as a cradle of biodiversity: A phylogeography of banded newts (genus Ommatotriton) reveals extensive inter- and intraspecific genetic differentiation. Molecular Phylogenetics and Evolution, 114: 73-81.

Schmitt T, 2007. Molecular biogeography of Europe: Pleistocene cycles and postglacial trends. Frontiers in Zoology, 4:11.

Suzuki H, Filippucci MG, Chelomina GN, Sato JJ, Serizawa K, Nevo E, 2008. A biogeographic view of Apodemus in Asia and Europe inferred from nuclear and mitochondrial gene sequences. Biochemical Genetics, 46: 329346.

Suzuki H, Sato JJ, Tsuchiya K, Luo J, Zhang Y-P, Wang Y-X, Jiang X-L, 2003. Molecular phylogeny of wood mice (Apodemus, Muridae) in East Asia. Biological Journal of the Linnean Society, 80: 469-481.

Suzuki H, Shimada T, Terashima M, Tsuchiya K, Aplin K, 2004. Temporal, spatial, and ecological modes of evolution of Eurasian Mus based on mitochondrial and nuclear gene sequences. Molecular Phylogenetics of Evolution, 33: 626-646.

Svenning J, Skov F, 2007. Could the tree diversity pattern in Europe be generated by postglacial dispersal limitation? Ecological Letters, 10:453-60.
Şeker PS, Selvi E, Kankılıç T, Çolak E, 2018. Geographical Distribution Pattern of Mitochondrial DNACytochrome b Diversity in Populations of Arvicola amphibius(Linnaeus, 1758) (Mammalia: Rodentia) in Turkeyas Determined by PCR-RFLP. Acta Zoologica Bulgarica, 70:19-30.

Tamura K, Stecher G, Peterson D, Filipski A, Kumar S, 2013. MEGA6: Molecular Evolutionary Genetics Analysis version 6.0. Molecular Biology and Evolution, 30: 2725-2729.

Veith M, Schmidtler JF, Kosuch J, Baran I, Seitz A, 2003. Palaeoclimatic changes explain Anatolian mountain frog evolution: a test for alternating vicariance and dispersal events. Molecular Ecology, 12: 185-199.

Vohralik V, Frynta D, Mikulova P, Benda P, Nova P, 2002. Multivariate morphometrics of Apodemus mystacinus in the Near east and its divergence from European A. m. epimelas (Mammalia: Rodentia). Israel Journal of Zoology, 48: 135-148.

Yiğit N, Çetintürk D, Çolak E, 2017. Phylogenetic assessment of voles of the Guentheri Group (Mammalia: Microtus) in Turkish Thrace and Western Anatolia. The European Zoological Journal, DOI: 10.1080/24750263.2017.1317041. 